\title{
気球を利用した無重力実験のための機体開発とそのフライト結果*1 Development of Vehicle for Balloon-Based Microgravity Experiment and Its Flight Results
}

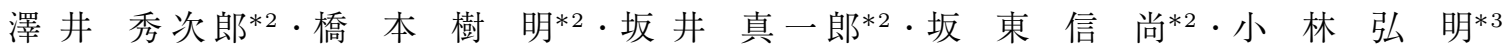 \\ Shujiro SawaI, Tatsuaki Hashimoto, Shin'ichiro Sakai, Nobutaka Bando, Hiroaki Kobayashi,

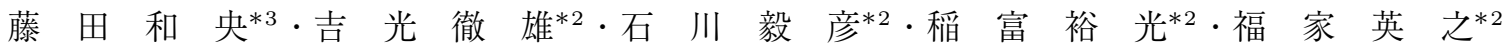 \\ Kazuhisa Fujita, Tetsuo Yoshimitsu, Takehiko Ishikawa, Yuko Inatomi, Hideyuki Fuke,

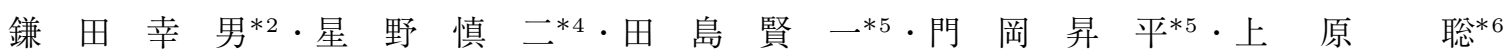 \\ Yukio Kamata, Shinji Hoshino, Ken'ichi Tajima, Shohei Kadooka, Satoshi Uehara,

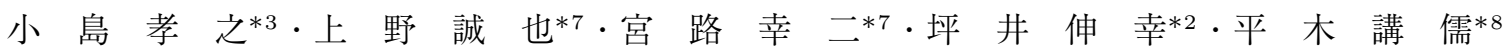 \\ Takayuki KoJıma, Seiya Ueno, Kouji MiYaJi, Nobuyuki TsuboI, Kouju HiraKI, \\ 鈴木 宏二郎*9 ·松 嶋清 穂*10 • 中 田 孝*10 \\ Kojiro Suzuki, Kiyoho Matsushima and Takashi Nakata
}

Key Words : Microgravity, Balloon, Drag-Free

\begin{abstract}
Rocket-shaped vehicle is developed to conduct microgravity experiment by dropping from the high-altitude balloon. Its design strategy and development status is introduced. Also, the result of its 2nd flight test is summarized to show the feasibility of the balloon-based microgravity experiment.
\end{abstract}

\section{1. は じめに}

著者らは，気球を利用した新たな無重力実験システムの 研究開発を推進している。この実験システムは, 高度 $40 \mathrm{~km}$ 以上の高高度まで重量物を浮揚させる新型の気球, その気 球から落下し良好な微小重力環境を創出する機体システム, および, 限られたリソースの中で効率的に無重力実験を行 うための実験支援システムから構成される. 本稿では, こ のうち, 機体システムについて, フライト結果とともに論 ずる.

\section{2. 気球を利用した無重力実験}

無重力実験を行うための手段としては, 落下塔を利用す るものや, 航空機実験, 宇宙空間での実験などが考えられ る1) が, 著者らのグループでは, 気球を利用した無重力実 験手段の構築を考えている ${ }^{2,3)}$. その特徵は, 比較的低い

\footnotetext{
*1 (C) 2008 日本航空宇宙学会

平成 20 年 1 月 7 日原稿受理

*2 宇宙航空研究開発機構宇宙科学研究本部

*3 宇宙航空研究開発機構総合技術研究本部

${ }^{* 4}$ 立教大学大学院

$* 5$ 武蔵工業大学大学院

*6 スーパーレジン工業 (株)

$* 7$ 横浜国立大学

$* 8$ 九州工業大学

*9 東京大学大学院新領域創成科学研究科

$* 10$ 藤倉航装 (株)
}

コストで, 良好な微小重力環境を $30 \mathrm{sec}$ から $1 \mathrm{~min}$ のオー ダーで実現できることである。気球を利用して無重力実験 を行うという考えは従来から存在する4 6) が，この計画で は, 落下中の機体にかかる様々な外乱が微小重力環境に与 える影響を排除するため, 微小重力実験部は機体内部で浮 遊するという 2 重殸構造となっている点で過去の例と異な り,これにより, 従来の方法では得られない良質な環境を 得ることができる.

シーケンスの概要を第 1 図に示す。高高度気球により高 度 $41 \mathrm{~km}$ 程度まで浮揚した機体は, 気球から切り離されて, 自由落下に入る. 自由落下中, 無重力実験を行い, その後, パラシュートを開傘することで減速, 洋上に着水する. 着 水された機体は回収船，ヘリコプターなどにより回収され， 整備の後，次の無重力実験に利用される.

\section{3. 機 体 の設 計}

3.1 機体概要 機体は, 全長 $4.0 \mathrm{~m}$, 代表直径 $0.556 \mathrm{~m}$ の細長い形状の機体であり，機体後部に空力安定のため 4 枚の尾翼が付いている (第 2 図参照). 機体主要部は CFRP 製であるが，先端部ノーズコーンは，コア材の発泡ウレタ ンの両側に GFRP スキンを貼り合わせたサンドイッチ構 造としている.これは, 電波透過性を確保し, その内部に 通信アンテナを配置することを意図している。また，尾翼 もサンドイッチ構造であるが，コア材を発泡ウレタン，ス 


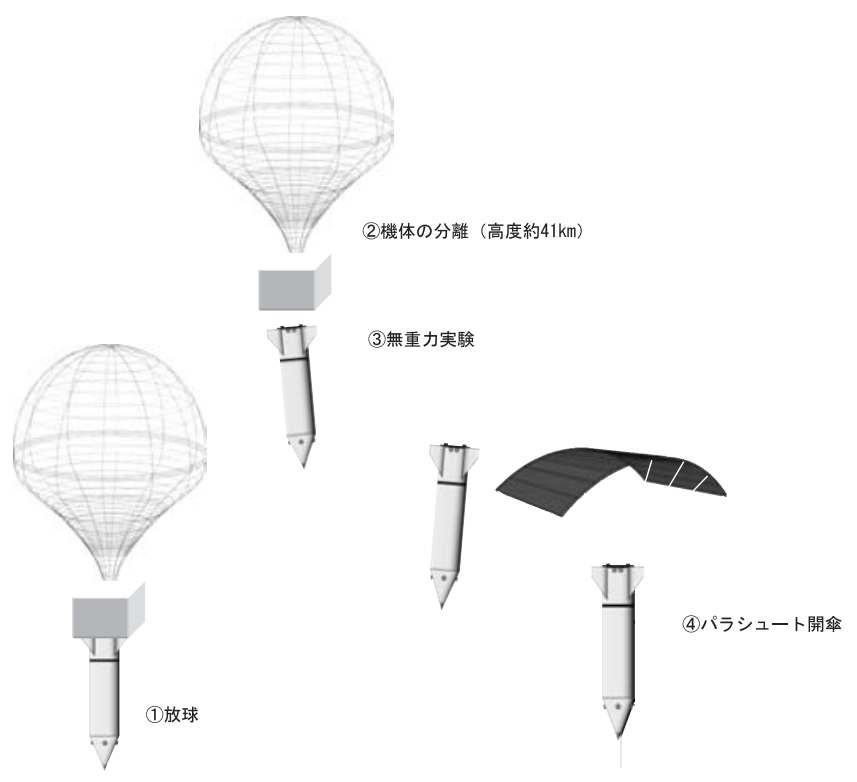

第 1 図 無重力実験シーケンス
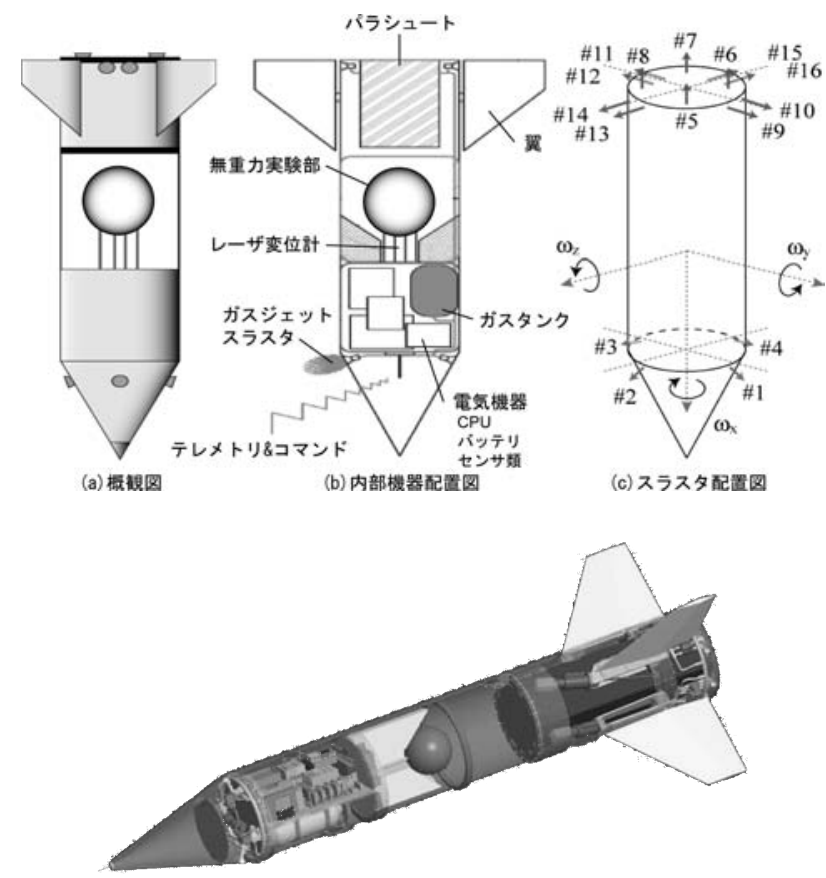

(d) 斜視㘡

第 2 図 無重力実験機体概要

キン材を CFRP とすることで, 重量を抑えつつ強度を確保 している．機体円筒部は，大きく 3 つの部分に分かれてお り, 機首寄りから, 主要機器搭載部, 無重力実験部, パラ シュート部となっている。このうち, 主要機器等細部と無 重力実験部は気密構造になっており, 上空でもほほ大気圧 を保持する一方，実験終了後，海上に着水したときに，内 部機器を海水から保護するとともに浮力を得る.

自由落下中，機体中央部にある球形の無重力実験部（以 下，「中子」と称する）は，機体に対して非接触で浮かぶよ う, 機体の位置・姿勢を 16 基のガスジェットスラスタで制
御する。それによって中子の内部では非常に良好な微小重 力環境が得られることになる。第 2 図 (c) にスラスタの配 置を示す．前部に搭載されたスラス夕\#1〜 \#4 は， $15 \mathrm{deg}$ の角度でキャントしているため，これらのスラスタを噴射 することで，機軸方向に後ろ向きの推力を得ることができ るようになっている。このことなどにより 6 自由度 12 方 向の制御力を発生することができる.

前述の通り, 無重力実験終了後は, 機体後端からパラシ ユートを開傘し，減速，緩降下し，洋上に着水する。着水 後は回収船，ヘリコプターにより回収され，機体は再利用 される。一般に構造設計においては，構造に加わる荷重を 想定し，それに耐えられるような強度や剛性を達成するよ う設計される。本機体では，構造強度を規定したのは，1) 放球時に気球から加わる衝撃的な加速度，2) 上空の希薄 大気中での気密構造部と外部の圧力差（ほほ $1 \mathrm{atmD}), 3$ ) 落下中の空力的な力, 曲げモーメント, フラッタ，4) パラ シュートの開傘衝撃抢よびその後の㐮引力，5) 洋上着水時 の衝撃，6) 着水後の最大潜水深さ近傍で気密構造部にかか る水圧，などであった。このうち, 着水時の衝撃の推定に あたっては，ペネトレータ貫入解析コードを元にした解析

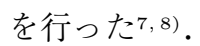

電源系については，圥長性の観点から別電源とした保安 回路系を除き $12 \mathrm{~V}$ 系, $24 \mathrm{~V}$ 系が各 2 系統の合計 4 系統と した.ノイズ対策として分離された各々の系統について，定 格容量が $27 \mathrm{Ah}$ のリチウムイオンバッテリを 1 台搭載し, 電力供給を実施した。

なお，ロケット実験などと比較し，気球実験は実験時間 が比較的長いため, 上空の低温環境での熱設計を含めた考 慮が必要となる，本機体では，温度環境が厳しくなるスラ スタバルブについて，断熱材とヒータによる熱制御を実施 することとした。

3.2 通信系設計 機体通信系は, 気球上昇中, 自由落下 中，およびパラシュートによる降下中の各フェーズで，既存 の地上局と適切にリンクを確保することが要求された．ダ ウンリンクは $1.6 \mathrm{GHz}$ 帯の 2 波であり, それぞれテレメト リデー夕と画像デー夕を地上に伝送する。アップリンクは $70 \mathrm{MHz}$ 帯の 1 波で，RS232C 仕様のシリアルコマンドを 地上から機体に送出するのに使用される.

各フェーズでは，機体は常に機首を下向きにしているた め, 通信系は, 機首側にある地上局とリンクがとれる必要 がある。また，機体軸周りの回転については，特に気球上 昇中，パラシュート降下中は制御していないため，機体軸 周りの回転位相に無関係にリンクが確保されていることが 条件となる。

これらの条件を満たすため，機体先端のノーズコーン部 全体を電波透過性のある素材で製作し，その中に， 3 つの アンテナ（テレメトリデー夕送出, 画像デー夕送出, コマ ンド受信）を配置することとした（第 3 図参照）.

な抄，第 4 図に示すように，地上にて受信したテレメト リ信号は復調され，まずテレメトリ保存・配信装置に渡さ れる。テレメトリ保存・配信装置は受け取った信号に地上 
での受信時刻を付加して保存するとともに，そのテレメト リをパケット化することで, 別の機器への配信が可能とな る.テレメトリ可視化装置はテレメトリ保存・配信装置に アクセスして，機上の現在の状態への工学值変換や履歴の グラフ化を実施する．機上の現在の状態や履歴のグラフは, 個々のユーザが持ちこんだパソコンのウェブブラウザから テレメトリ可視化装置にアクセスすることにより閲覧可能 である。このため，ユーザは特別な装置を用意する必要は ない。

3.3 空力設計 機体は, 空気抵抗をなるべく小さくし, かつ, 空力的に姿勢が安定であることが望まれる. その一方

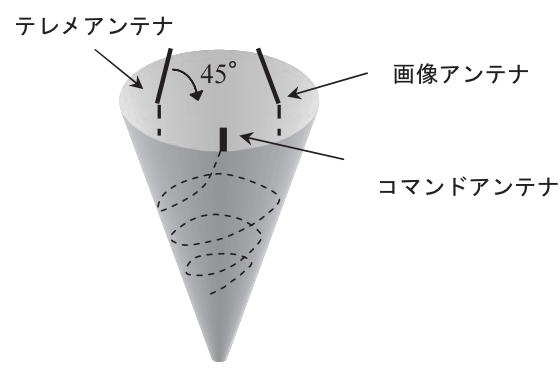

第 3 図 アンテナ配置

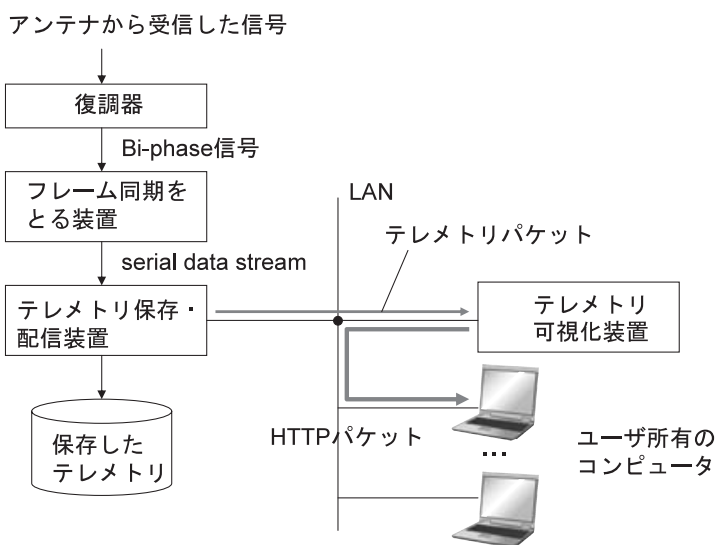

第 4 図 地上支援系の概要

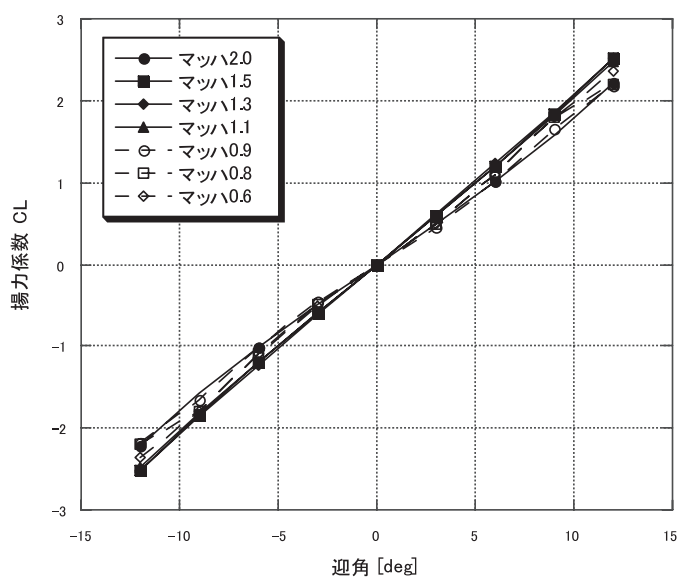

で,リソース制約のため, なるべく単純な形状 (円形, 平面 など）の組み合わせで機体を製作したいという要求があり, 機体前方は単純な円錐形状とする, 機体後端はパラシュー ト開傘のために筒状にストレートのままにする，など，空 力設計以外の条件で形状が設定されている。この制約下で, 空力的に姿勢安定が保たれるよう尾翼を設計し，また，空 力係数を推定することが, 空力設計に求められる. 数值解 析, 風洞試験などを経て, 第 5 図のように空力係数が推定 された。

3.4 制御系の設計 空力設計結果より, 空気抵抗は最大 で $100 \mathrm{~N}$ 程度発生すると推定された。それを元に, デュー ティ最大 $50 \%$ 程度で空気抵抗をキャンセルできる能力を有 するスラス夕系として，後ろ向きに $50 \mathrm{~N}$ 級スラスタを 4 基 配置することとした。このサイジングを元に，16 基の $50 \mathrm{~N}$ スラスタ（高圧空気噴射によるコールドガスジェットスラス 夕）を機体に配置した。制御系の周期は $8 \mathrm{~Hz}$ であり，空気 抵抗に関する予想值を元にしたフィードフォワード制御と, $\mathrm{PD}$ 制御器によるフィードバック制御を組み合わせた構成 とした。すなわち，機体制御系は，16 基のスラス夕を使用 し, 搭載したジャイロに基づく姿勢安定化の他, 機体内壁 と無重力実験を行う中子が衝突しないよう, 落下中の機体 の制御を行う ${ }^{9)}$.このとき, 並進方向制御としては, 機体内 壁と中子の隙間が, ゼロにならないよう制御系は制御力を 出し続けることになる。そのため, 制御の観点では, 隙間 は大きい方が望ましいが，一方で，機体の大きさが決まっ ている中で隙間を大きくすると, 中子のサイズが小さくな るため, 無重力実験スペースが限られることになる。この 隙間については，ガスジェットスラスタが発生する制御力 より決定した。デューティ $50 \%$ の $50 \mathrm{~N}$ スラスタ 4 基を噴 射した場合, 静止状態の $300 \mathrm{~kg}$ の機体は, $0.5 \mathrm{sec}$ (制御周 期 4 サンプル分）の間に $0.08 \mathrm{~m}$ 程度移動することなどを 参考に, $0.1 \mathrm{~m}$ 以上の隙間を確保することを機体設計条件 とした。

中子位置の計測は，機体に固定された 4 台のレーザ変位 計を利用して実施した。 中子は機体に対して並進 3 自由度

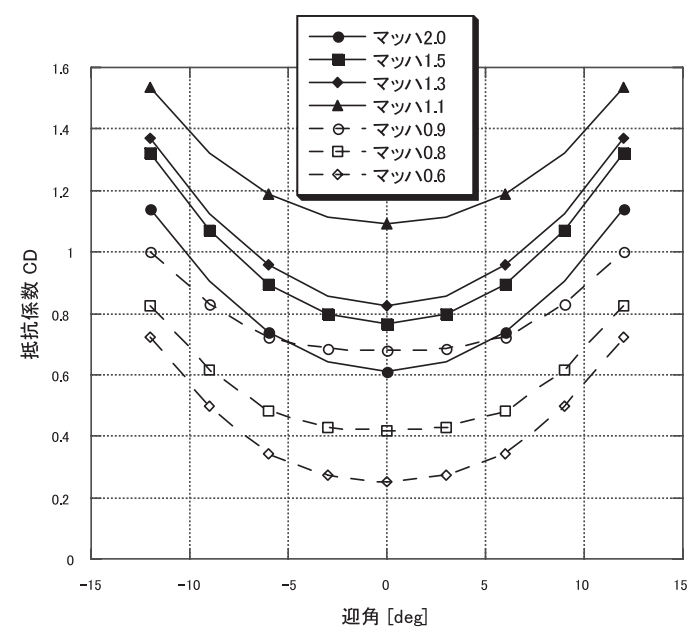

第 5 図 推定された機体空力係数 


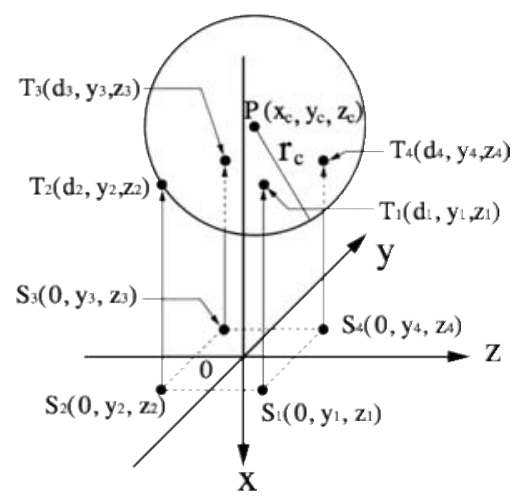

第 6 図＼cjkstart無重力実験部とその位置推定用レーザ変位計配置

ともに $0.1 \mathrm{~m}$ オーダー移動しても, 位置計測ができる必要 がある．また，中子の姿勢変動は機体から制御できないこ ともあり, 姿勢変動があってもロバストに計測できること が望まれる。

そのため, この機体では, 中子の下半分を球形にし，下 側から 4 本のレーザ変位計を平行に照射し，球形の各部の 距離を計測することにした (第 6 図参照)。ここでレーザ 変位計は, 図中の $S_{i}(i=1 \sim 4)$ の 4 箇所に設置されてお り，図の $-x$ 軸方向にレーザを照射している。それにより， レーザは中子表面の $T_{i}(i=1 \sim 4)$ に達することで， $S_{i}$ と $T_{i}$ の距離 $d_{i}(i=1 \sim 4)$ を計測する. レーザ恋位計の機体 での設置位置，レーザ照射方向および中子半径は既知であ るため,

$$
\begin{aligned}
& \left(d_{1}-x_{\mathrm{c}}\right)^{2}+\left(y_{1}-y_{\mathrm{c}}\right)^{2}+\left(z_{1}-z_{\mathrm{c}}\right)^{2}=r_{\mathrm{c}} \\
& \left(d_{2}-x_{\mathrm{c}}\right)^{2}+\left(y_{2}-y_{\mathrm{c}}\right)^{2}+\left(z_{2}-z_{\mathrm{c}}\right)^{2}=r_{\mathrm{c}} \\
& \left(d_{3}-x_{\mathrm{c}}\right)^{2}+\left(y_{3}-y_{\mathrm{c}}\right)^{2}+\left(z_{3}-z_{\mathrm{c}}\right)^{2}=r_{\mathrm{c}} \\
& \left(d_{4}-x_{\mathrm{c}}\right)^{2}+\left(y_{4}-y_{\mathrm{c}}\right)^{2}+\left(z_{4}-z_{\mathrm{c}}\right)^{2}=r_{\mathrm{c}}
\end{aligned}
$$

ただし

$\left(x_{i}, y_{i}, 0\right):$ レーザ変位計 $s_{i}$ の計測基準点

$d_{i}:$ レーザ変位計 $s_{i}$ の計測距離

$\left(x_{\mathrm{c}}, y_{\mathrm{c}}, z_{\mathrm{c}}\right)$ : 中子下側の半球の中心位置

$r_{\mathrm{c}}$ : 中子下側の半球の半径

を満たす．よって，この 4 つの式を連立させることで，中 子の 3 次元位置 $\left(x_{\mathrm{c}}, y_{\mathrm{c}}, z_{\mathrm{c}}\right)$ が推定される。一般には, 中 子形状は既知であれば球形である必要はなく，また，レー ザ変位計の数が最低 3 本あれば, 並進 3 自由度の位置推定 は行うことができる。中子形状を球形にしたのは，中子の 姿勢変動が計測に与える影響を小さくすることを意図して いる．また，レーザ変位計を 4 本にしたのは，1本のレー ザ計測が不調だったときに対応するための圥長構成である。 特に, 中子が横方向に大きくずれたとき, レーザ変位計の 中には球形の端に近い部分の計測を行うものが出てくるこ とになり，計測が不調になることも懸念される，その対策 として，4本のレーザ変位計を利用した圥長構成とした。

3.5 パラシュート設計 高高度気球から落下寸る機体 は，与えられた制約条件の中で, 空気抵抗がなるべく小さ

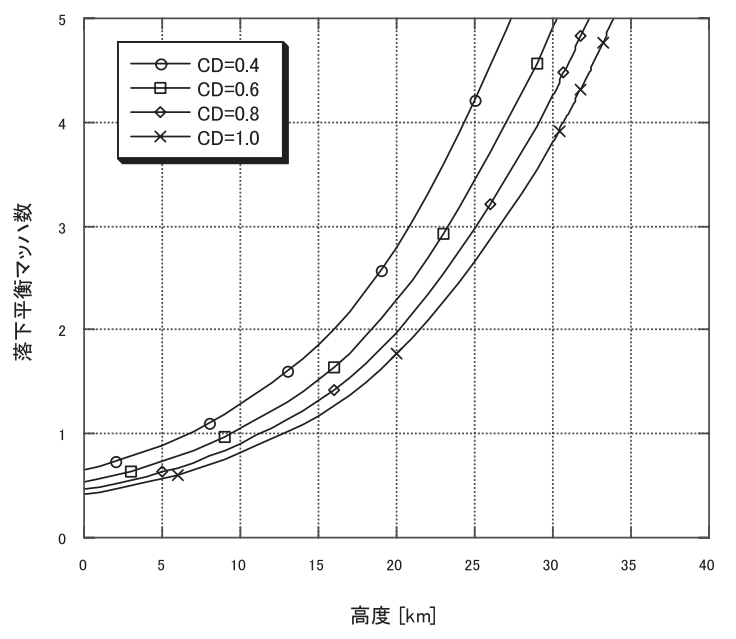

第 7 図 平衡落下速度

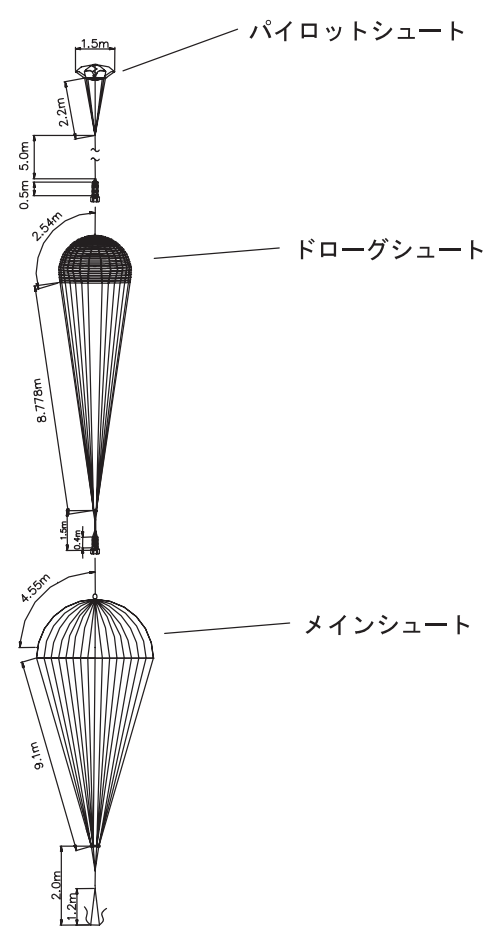

第 8 図 パラシュートの構成

くなるように設計される. そのため, 無重力実験終了後, ガ スジェットによる空気抵抗補償を終えた後も，パラシュー 卜開傘などを行わない限り，機体は暫くの間， $1 \mathrm{G}$ より小 さいものの加速を続ける. 第 7 図に, 機体の平衡速度を示 す. 空気抵抗係数に依存するものの平衡速度がマッ八 1 を 下回るのは, 高度 $10 \mathrm{~km}$ 前後と低く, しかも空力倸数に対 する誤差感度も比較的大きいなど，リスクがある。そこで, 本機体では, 無重力実験を終了したら, 超音速状態であっ ても，ただちにパラシュートを開金する方針を選択した。

第 8 図に示すように，パラシュートは，パイロットシュー ト，ドローグシュート，メインシュートの 3 つから構成さ れる。無重力実験終了と同時に押しバネにより小型のパイ ロットシュートを放出する。 そのパイロットシュートの展 
張力を利用し，その直後にドローグシュートが放出される. この 2 つのパラシュートは, 超音速での展張となる。この ため, パイロットシュートにはバネを内蔵したリブレスガ イドサーフェイス傘を新規開発し，ドローグシュートには ヘミスフロー傘を選択している.

ドローグシュートによる第 1 段階の減速の後, 高度 $8 \mathrm{~km}$ を下回った時点で, ドローグシュートを切り離し, メイン シュートに切り替える。パラシュートのサイジングにおい ては, 構造設計とのインタフェース条件として, 開傘衝撃 $10 \mathrm{G}$ 以下，着水速度 $10 \mathrm{~m} / \mathrm{sec}$ を設定した。

本パラシュート系では, システム構成をシンプルとする ため，パイロットシュートをバネ力によって押し出す．その ため, 押し出し力は比較的弱いため, 機体後端から放出さ れる際，ウェーク領域から抜け出すことができるか検討が 必要である. そのため, まず数值解析によりウェークの様子 を推算し, 次にその予想されたウェークに対して, パイロッ トシュート放出シミュレーションを行った。 その結果, パ イロットシュート放出用バネとして, バネ定数 $250 \mathrm{~N} / \mathrm{m}$ 以 上, 縮み量 $500 \mathrm{~mm}$ 以上のバネを利用すれば十分にウェー ク領域を抜け出すことができることがわかった.

\section{4. フライト結果概要}

前節で概説した機体（第 9 図参照）は，2007 年 5 月 29 日午前 5 時 56 分, 宇宙航空研究開発機構宇宙科学研究本 部の三陸大気球実験場より放球され, 無重力実験が実施さ れた後, 洋上に着水 (第 10 図参照) し, 回収された。実験 中, 機体は, 第 11 図に示すような軌跡を辿り, 午前 9 時 37 分に, 地上からのコマンドにより実験準備シーケンスを起 動, その $4.5 \mathrm{~min}$ 後に, 内部タイマにより落下実験が開始 された。落下開始高度は $41.36 \mathrm{~km}$ であった。落下（ $X$ 時 刻）の $35 \mathrm{sec}$ 後にパイロットシュート・ドローグシュート 開傘， $X+4 \min 57 \sec$ にメインシュートを開傘した。第 10 図に示すように, GPS データは, 落下中の一時期ロッ クオフしたものの, メインシュート開傘に至るまで, 機体 の位置情報を送出し続けており, また, 無重力実験期間中,

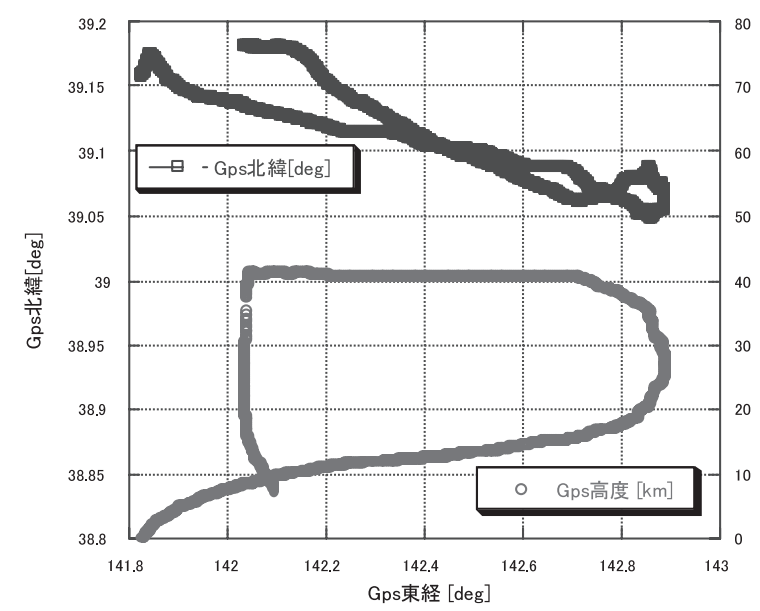

GPS データは約 $1 \mathrm{sec}$ の時間遅れはあるものの, 自由落下 を仮定した場合の軌跡とほぼ一致することがわかる．この ことより, パラシュート開傘の時点で機体はマッハ 1.2 程 度に達したと考えられる。

第 12 図に, 機体気密部の圧力履歴を示す. 機体の主要機 器搭載部と, 中子が運動する無重力実験部は, 気密構造の 中に入っている。この図には，あわせてリークがないとし た場合の内部空気の推定温度もプロットしている。この図 から, 高度 $20 \mathrm{~km}$ より上では, 内部の温度低下がほとんど

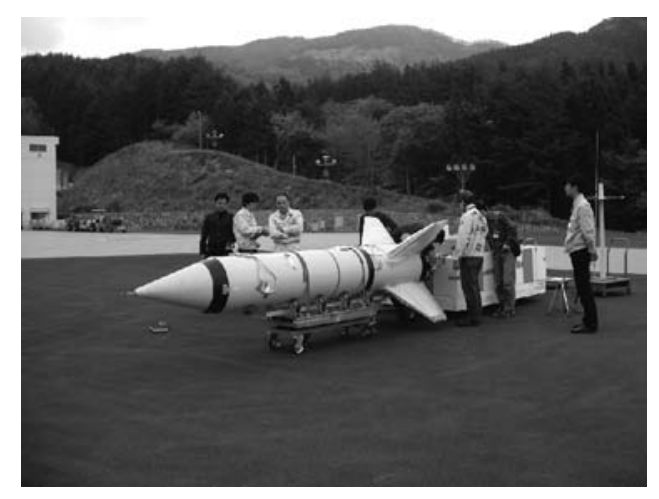

第 9 図 放球前整備中の実験機体

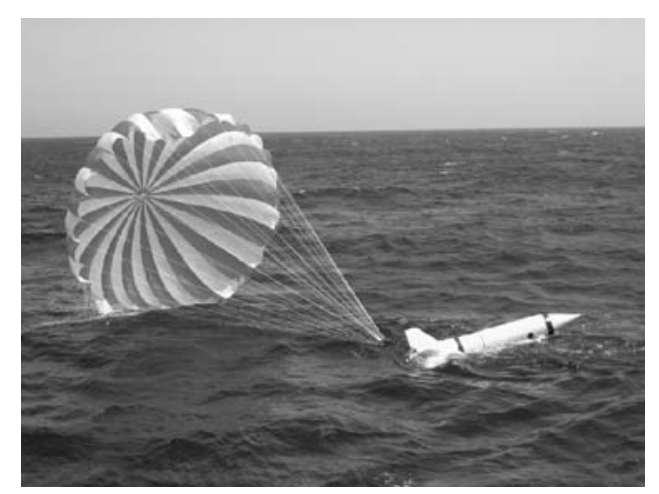

第 10 図 無重力実験終了後に洋上に浮かぶ実験機体

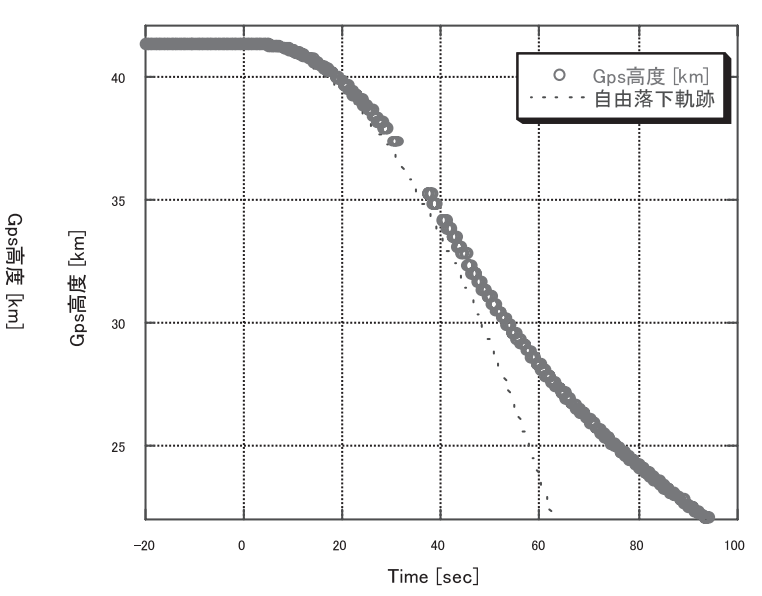

第 11 図 気球実験時の機体軌跡 


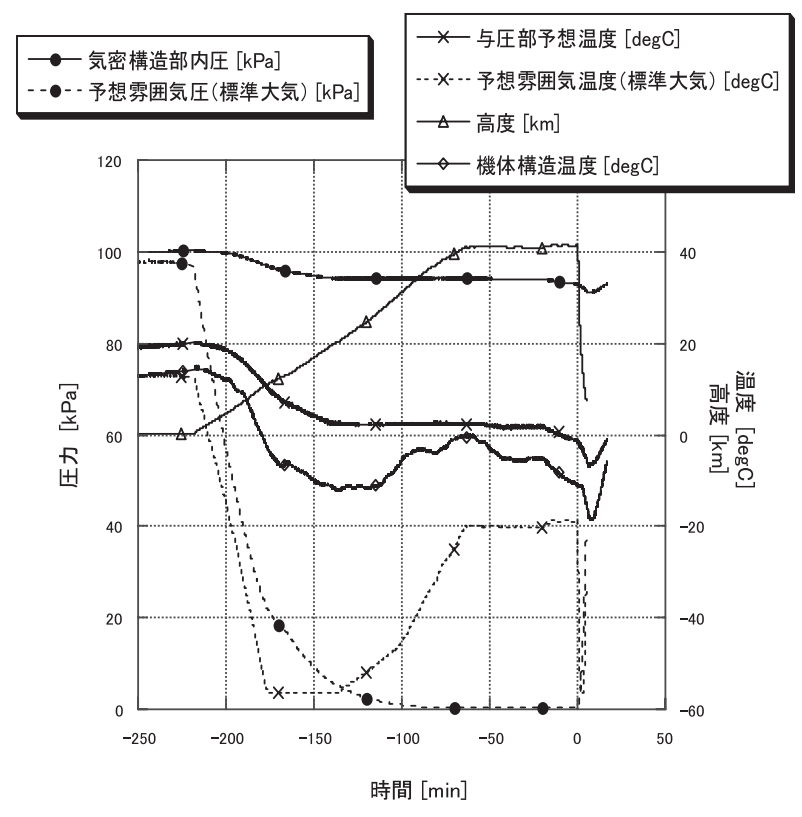

第 12 図 気密構造部の内圧履歴

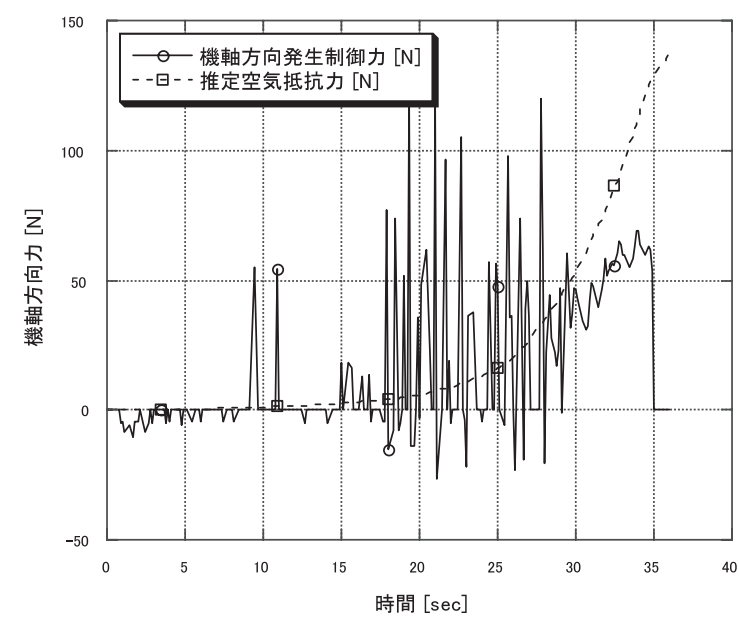

第 13 図 機軸方向の発生制御力と推定された空気抵抗

見られないことがわかる。 また，落下直前に高度を上げる タイミングや機体落下時に, 気密部の圧力低下が観測され ている。この原因を考えるための参考情報として，同図に は機体構造部の温度データとして機体胴体部 CFRP 部の温 度履歴も示している。この温度履歴が, 気密部圧力履歴や そこから推定した内部空気温度履歴と同様の傾向を示して いることから, 気密部圧力変化の主要原因は, 漏洩ではな く, 機体高度変化に伴い, 何らかの理由で温度低下が起き ているためと考えられる。なお，この現象は温度制御の許 容範囲内であることから, フライトにとって問題とはなら

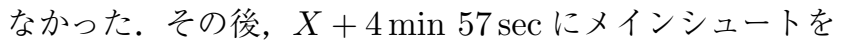
開傘した後の, $X+6 \mathrm{~min}$ 前後から圧力や温度は急激に回 復している。このことからも, 落下直前の急激な気球上昇 や落下中の高速落下のように, 大気中を機体が高速で通過 すると内部温度の低下を招くものと考えられる。

第 13 図には，落下実験中にガスジェット噴射による発生制

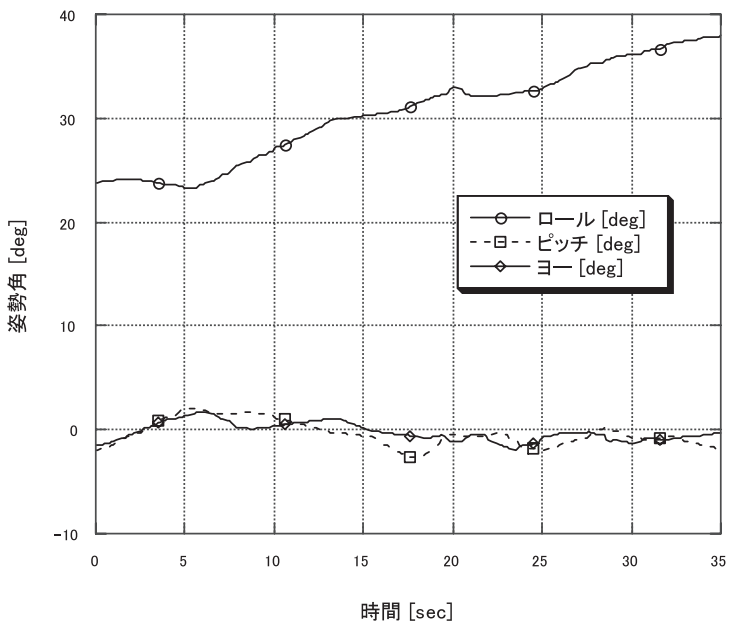

第 14 図 落下実験中の姿勢履歴
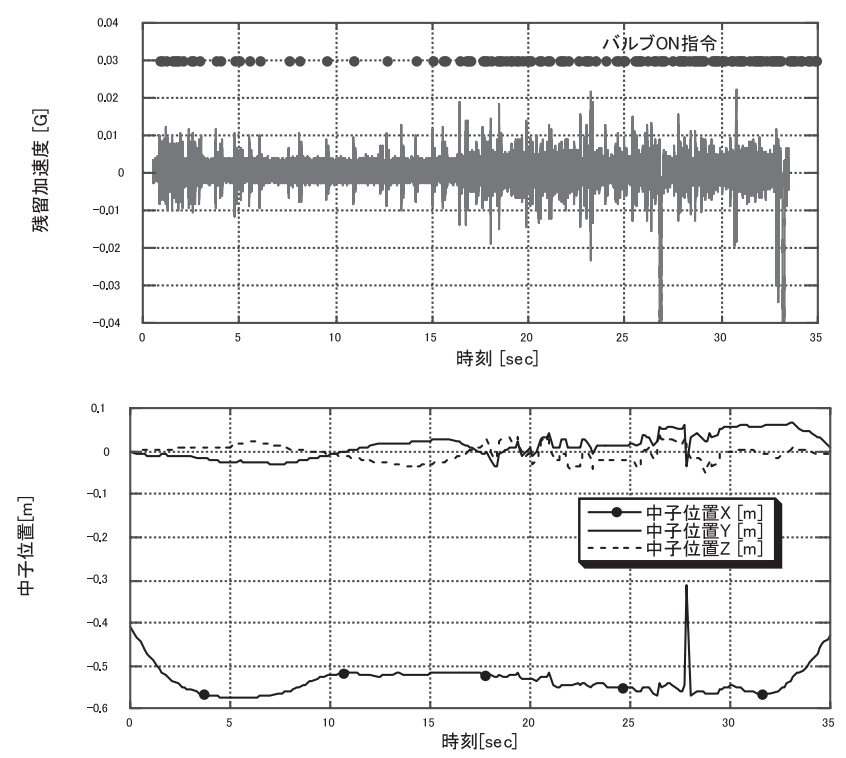

第 15 図 落下実験中の無重力実験部の残留加速度履歴

御指令值と，予想された空気抵抗の関係を示す． $X+25 \mathrm{sec}$ 程度までは, 空気抵抗が小さく, 小さな噴射指令が多いこ ともあり, 発生制御力の変化が大きい. そのため, 後半部 分だけで比較する。その場合，発生制御力は予想された空 気抵抗に対して，35\%程度小さい. これは, 空気抵抗係数 を $35 \%$ 程度大きめに見積もっていた可能性を示唆する。

第 14 図に，落下中の機体の姿勢履歴を示す. 姿勢のう ち, ピッチ回転, ヨー回転については, 目標值をゼロとす る一方, 機体のロール回転については, 中子の衝突と直接 の関係がないため, レートをゼロに抑えることを目標とし て制御を実施している。ピッチ，ヨー軸の姿勢はほぼ安定 していること，また，ロールについては，外乱によりドリ フトしていくものの, いわゆるスピン剛性が影響するよう な回転とはなっておらず，制御が正常に行われたことがわ かる。

第 15 図に, 中子内部での残留加速度履歴を示す．残留加 速度は，中子内で 3 軸の加速度計測を行っているが，大きな 
差異はなかったため, ここでは代表的な 1 軸のみを示して いる。 また, 図中, ガスジェット噴射指令が発行されたタイ ミングや, 中子位置の計測結果履歴もあわせて表示してい る. 中子位置については, $x$ 軸が機軸方向であり, $-0.55 \mathrm{~m}$ を制御目標としており，また， $y, z$ 軸は機軸直交方向であ り，0.00 m を制御目標としている。制御目標からの許容誤 差は中子と機体の隙間次第であるが，前述のように $0.1 \mathrm{~m}$ の誤差を許容するように設計されている。この図によると， 自由落下開始直後から，定常的に外乱が発生していること がわかる。このうち，比較的大きく不定期の外乱は，ガス ジェットスラスタの噴射と同期しており，ガスジェットの噴 射音が中子に伝達したのが原因であると考えられる。これ は, 無重力実験部を気密構造とし, 中子は大気圧に与圧し た内部を自由に運動することとしたため, 空気によって，ガ スジェットスラスタの噴射音が浮遊している中子に伝わった と考えられる。この対策としては，防振処置などによりガ スジェットスラスタ噴射による振動擾乱の伝達を抑制する ことの他，無重力実験を実施するユーザが許容すれば，無 重力実験部自体を減圧することなども考えられる。

また，図中，定常的なノイズもあるが，これは $150 \mathrm{~Hz}$ 程 度の振動であり，フライト後の検証により，中子の中に搭 載していたビデオカメラのモータ駆動が原因であったこと が判明した．無重力実験を行うユーザが決定すべき事柄で はあるが，中子内部に駆動機構を搭載しないようにすれば, この外乱は除去できる.

また， $X+27 \mathrm{sec}$ あたりで，衝撃的な加速度外乱が計測 されているが，これは中子が機体と接触したためと考えら れる。この直前で, 中子の位置推定が不連続に変化してい ることからも見てとれる。この原因であるが，中子が自由 落下開始直後に回転してしまい， $X+26 \mathrm{sec}$ あたりで，一 部のレーザ変位計が中子下半分の球形部分に当たらなくな り, 中子位置推定が大きな誤差を持つようになったためと 考えられる。前述のように中子の位置推定は, レーザが照 射される部分は球殼を形成しているという仮定に基づいて 行っている一方, 実際に中子が球殼を形成しているのは下 半分だけであるため, 中子が $90 \mathrm{deg}$ 近く回転すると, 中子 位置の推定誤差が大きくなる。中子は, 機体自由落下開始 時に姿勢外乱が入ると，自由落下中はそれを抑制すること ができない，そのため，自由落下開始時に，姿勢外乱をな るべく低減したリリースを工夫する必要があることがわか る。なお，中子が回転することに起因して発生する遠心力 自体は， $30 \mathrm{sec} て ゙ 90 \mathrm{deg}$ 回転する程度の角速度であっても 十分に小さいレベルである。

第 16 図に，残留加速度の周波数分析結果を示す．ただ し, ビデオモータ駆動振動については, 除去した後のデー 夕を用いている。これは, $150 \mathrm{~Hz}$ の振動は機体系に起因し たものではないことより, 無重力実験のユーザ側にて発生 を抑制することが可能であることによる．第 16 図には，ガ スジェットスラスタの噴射がなかった期間を切り出して周 波数分析した結果や国際宇宙ステーションで要求されてい るレベルもあわせてプロットしている。この図で，低周波

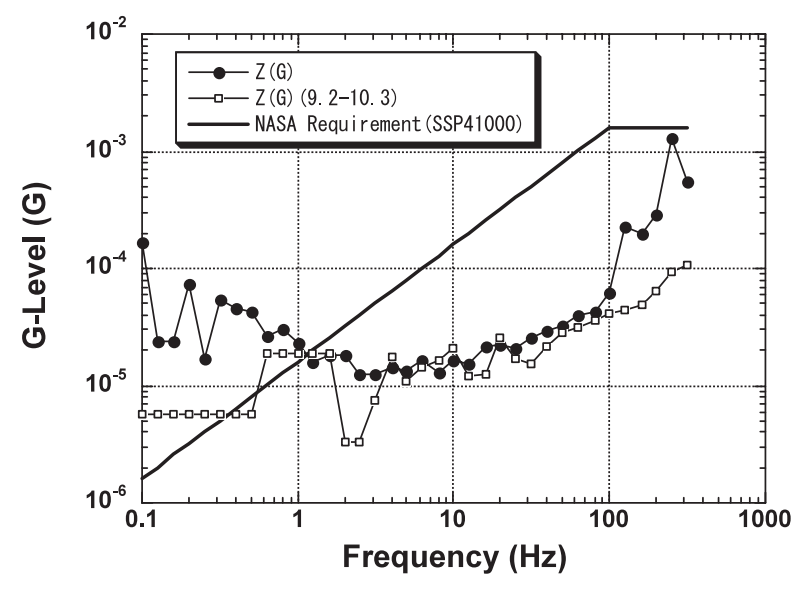

第 16 図 残留加速度の周波数解析

側で大きい值となっているのは分析に使用したデータの時 間が短かったためと思われる。たとえば， $0.1 \mathrm{~Hz}$ の振動の 周期は $10 \mathrm{sec}$ であるのに対して, 本実験システムでは実験 時間が全体で $30 \mathrm{sec}$ オーダーである。それを考慮すると， 本実験では，中子に駆動機構を搭載しなければ，ガスジェッ トスラスタの噴射対策を施す前の状態であっても，国際宇 宙ステーションで要求される微小重力環境レベルをクリア できていることがわかる。

\section{5. まとめと今後の課題}

以上，気球を利用した無重力実験システムのうち，落下 機体の開発状況抢よびフライト結果をまとめた。. 現状で, 既 に良好な微小重力環境を提供できる機体となっていること はフライト結果よりわかる，今後，より良質な微小重力環 境をより長時間提供することを目指すとともに，無重力実 験を行う実験者の立場に立った運用性の向上を目指した機 体の改良を行う予定である。運用性という観点では, 現状, 無重力実験機材は放球の $2 \sim 3$ 日前に機体側に引き渡され る必要がある。これをたとえば，放球の 3 時間前の引き渡 しで対応できるよう，大型アクセスパネルがある機体構造 の設計などを行いたい。

また，今回の実験結果により，気球を利用することで超 音速飛行実験が可能であることが実証されている。このこ とから，このシステムを，たとえば将来のスペースプレー ン実現に必要な技術を習得する手段として活用することも 考えることができる10).

本研究は, 文部科学省科学研究補助金 (学術創成 $(2)$ : $16 \mathrm{GS} 0220$ 「高高度気球を用いた微小重力実験装置の開発」) を受けて行われている.

\section{参 考 文 献}

1) Thomas, V. A., Prasad, N. S. and Reddy, C. A. M.: Microgravity Research Platforms-A Study, Curr. Sci., 79 (2000), p. 340.

2) 稲富裕光, 石川毅彦, 橋本樹明, 澤井秀次郎, 斉藤芳隆, 吉光徹 雄, 坂井真一郎, 小林弘明, 藤田和央, 坂東信尚, 後藤雅享, 神 保 至, 山川 宏: 高高度気球からの微小重力実験用自由落下力 
プセルの第一回飛行試験, 日本マイクログラビティ応用学会誌, 23 (2006), pp. 197-203.

3) Hashimoto, T., Sawai, S., Saito, Y., Inatomi, Y., Ishikawa, T., Yoshimitsu, T., Sakai, S., Kobayashi, H., Fujita, K., Bando, N. and Yamakawa, H.: Micro-Gravity Test System Using Free-Fall Capsule from High Altitude Balloon, Proceedings of 25th ISTS, 2006-h-04, 2006.

4) 並木道義, 太田茂雄, 秋山弘光, 山上隆正, 狛 豊, 西村 純： 大気球による無重力実験, 宇宙研報告特集, 第 4 号 (1982), pp. $27-46$.

5) Namiki, M., Ohta, S., Yamagami, T., Koma, Y., Akiyama, H., Hirosawa, H. and Nishimura, J.: Microgravity Experiment System Utilizing a Balloon, Adv. Space Res., 5 (1985), pp. 83-86.

6) Sommer, K., Kretzschmar, K. and Dorn, C.: Extension of Drop Experiments with the MIKROBA Balloon Drop Facility, Microgravity Sci. Technol., 5 (1992), pp. 166-171.

7) Suzuki, K., Abe, T., Higuchi, K., Fujimura, A. and Mizutani,
H.: Development of Analysis Model of Penetration Dynamics for Lunar-A Mission, Proceedings of 20th International Symposium on Space Technology and Science, 1996, pp. 10871092.

8）鈴木宏二郎, 白石浩章, 水谷 仁: 砂密度分布を考慮した月ペネ トレータ貫入ダイナミクス解析, 第 42 回宇宙科学技術連合講演 会論文集，1998, pp. 655-660.

9) Bando, N., Tajima, K., Sakai, S., Inatomi, Y., Ishikawa, T., Kobayashi, H., Fujita, K., Fuke, H., Sawai, S. and Hashimoto, T.: Development of Control System for Micro Gravity Experimental System from High Altitude Balloon, IAC-07-A2.3.08, The 58th International Astronautical Congress, 2007.

10) Fujita, K., Sawai, S., Kobayashi, H., Taguchi, H., Okai, K. and Sato, T.: Precooled Turbojet Engine Flight Experiment Using Balloon-Based Operation Vehicle, Acta Astronautica, 59 (2006), pp. 263-270. 